\title{
Breast cancer or an insidious disease? Idiopathic granulomatous mastitis, its ultrasonographic, dynamic contrast-enhanced MR and diffusion MR characteristics with a literature review
}

\section{Meme kanseri mi yoksa benign bir antite mi? İdyopatik granülomatöz mastit; Ultrason, diffüzyon MR ve dinamik kontrastlı MR özellikleri ve literatür derlemesi}

\author{
Şehnaz Tezcan' ${ }^{1}$, Funda Ulu Öztürk1, Nihal Uslu' ${ }^{1}$, Eda Yılmaz Akçay² \\ ${ }^{1}$ Başkent Üniversitesi Tıp Fakültesi, Radyoloji Bölümü, Ankara, Türkiye \\ ${ }^{2}$ Başkent Üniversitesi Tıp Fakültesi, Patoloji Bölümü, Ankara, Türkiye
}

Dergiye Ulaşma Tarihi: 13.09.2017 Dergiye Kabul Tarihi: 05.10.2017 Doi: 10.5505/aot.2017.97268

\section{ÖZET}

Giriș: İdyopatik granülomatöz mastit, radyolojik olarak meme kanserini taklit edebilen, nadir görülen, benin iltihabi bir meme hastalığıdır. Ultrason ve manyetik rezonans bulguları tanıda yardımcı olmaktadır. Bu çalışmada idyopatik granülomatöz mastitin ultrason, difüzyon ağırlıklı ve dinamik kontrastlı MR bulgularını irdelemeyi amaçlamaktayız.

Yöntem ve Gereçler: Çalışmaya 12 hasta dahil edilmiştir. Tüm hastalara ultrason, difüzyon ağırlıklı MR ve dinamik kontrastlı MR tetkikleri uygulanmıştır. Lezyonların morfolojik özellikleri, görünür difüzyon katsayıları ve zaman-sinyal intensite eğrileri değerlendirilmiştir.

Bulgular: Ultrason ve MR incelemesinde hastalarda heterojen kitleler ve bunlara eşlik eden dilate duktal yapılar izlenmiştir. Dinamik kontrastlı MR'da; lezyonlar içerisinde kitlesel kontrastlanma, kitlesel olmayan kontrastlanma ve halkasal kontrastlanma paternleri gözlenmiştir. Zaman-sinyal intensite eğrilerinde tip 1, tip 2 ve tip 3 kontrastlanma özellikleri izlenmiştir. 1 hastada zaman-sinyal eğrisinin steroid tedavisi sonrasında tip 3'den tip 1'e gerilediği dikkati çekmiştir. Lezyonların ortalama görünür difüzyon katsayısı değeri $1.01 \pm 0.06(\times 10-3 \mathrm{~mm} 2 / \mathrm{s})$ olarak hesaplanmıştır.

Tartışma ve Sonuç: İdyopatik granülomatöz mastit ile meme kanseri ayrımında dinamik kontrastlı MR bulguları genelde tanıya yardımcı olsa da, idyopatik granülomatöz mastit seyrek de olsa meme kanserine benzer olarak tip 3 kinetik eğriler gösterebilmektedir. Bununla beraber kanserden farklı olarak idyopatik granülomatöz mastitte izlenen tip 3 kinetik eğri ilaç tedavisi sonrası tip 1 eğriye dönüşebilmektedir. İdyopatik granülomatöz mastitte lezyonlardan elde edilen görünür difüzyon katsayısı ise kanserlere benzerlik göstermektedir. İdyopatik granülomatöz mastitin tanısının kesinleşmesinde hala biyopsi önemini korumaktadır.

Anahtar Kelimeler: İdyopatik granülomatöz mastit, dinamik kontrastlı MR, difüzyon MR, görünür difüzyon katsayısı

\begin{abstract}
Introduction: Idiopathic granulomatous mastitis is a rare, benign inflammatory breast disease which can mimic breast carcinoma radiologically. Ultrasound and magnetic resonance imaging findings may help for diagnosis. The aim of this study is to evaluate ultrasound, MRI, diffusion-weighted and dynamic contrast-enhanced MRI findings of idiopathic granulomatous mastitis.

Material and Methods: 12 patients were enrolled in this study. All patients were examined with ultrasound, diffusion-weighted and dynamic contrast-enhanced MRI. Morphological characteristics, apparent diffusion coefficient values and time-intensity curves of lesions were evaluated.

Results: Ultrasound and non-contrast magnetic resonance imaging showed heterogenous masses and dilated ducts. Non-mass-like enhancement, mass-like enhancement and ring-like enhancement were identified on dynamic contrast-enhanced MRI. Lesions showed type 1, type 2 or type 3 enhancement patterns. Type 3 curve changed into type 1 curve after steroid therapy in one patient. The mean apparent diffusion coefficient value of lesions was 1.01 $\pm 0.06(\times 10-3 \mathrm{~mm} 2 / \mathrm{s})$.
\end{abstract}

Discussion and Conclusion: Dynamic contrast-enhanced MRI findings may generally help to differantiate malignancy from idiopathic granulomatous mastitis, however, idiopathic granulomatous mastitis can show type 3 
kinetic curves rarely, similar to malignancy. Neverthless, type 3 curves can change to type 1 curves after drug therapy in idiopathic granulomatous mastitis contrast to malignancy. Apparent diffusion coefficient values of idiopathic granulomatous mastitis were similar to malignancies. For definite diagnosis, biopsy still remains its importance of diagnosis for idiopathic granulomatous mastitis.

Keywords: Idiopathic granulomatous mastitis, dynamic contrast-enhanced MRI, diffusion-weighted MRI, apparent diffusion coefficient

\section{Introduction}

Idiopathic granulomatous mastitis (IGM) is a rare, chronic inflammatory breast disease of unknown etiology. It's ability to mimic breast carcinoma clinically and radiologically underlines its importance. IGM can impair the life quality due to high recurrence rates after treatment, often resulting in multiple reoperations or drug therapies to achieve cure. It's characterized pathologically by the presence of chronic granulomatous inflammation of the lobules without necrosis (1). Breast mass, pain and skin lesions are the most common symptoms of IGM (2). It is difficult to treat IGM especially if presented with fistula and abscess formation, thus early diagnosis of IGM can increase the rate of treatment success and decrease the recurrence rate. Histopathology is essential to make a definitive diagnosis to reduce frequency of unnecessary mastectomies. Therefore, adequate recognition of its radiological patterns is vital to differentiate it from malignancy. Even though, mammography, ultrasound (US) and noncontrast magnetic resonance imaging (MRI) findings of IGM have been previously reported, diffusion-weighted MRI (DWI) and dynamic contrast-enhanced MRI (DCE-MRI) findings of IGM have not been clearly described until now $(1,2)$. The purpose of this study to evaluate US, MRI, DWI and DCE-MRI findings of IGM in twelve patients prior to biopsy and compare imaging findings with breast malignancy.

\section{Material and Methods}

Between April 2011 and December 2015, 12 women with histopathological diagnosis of IGM were evaluated with US, DCE-MRI and diffusion MRI prior to biopsy. The diagnosis was established with US-guided tru-cut biopsy in ten cases and excisional biopsy in two patients.

All patients were examined with US, DCE-MRI and diffusion MRI. High resolution real-time US images were obtained with a $9.4 \mathrm{MHz}$ linear-array transducer (Siemens Acuson 3000). MRI was performed with $1.5 \mathrm{~T}$ MRI system ((Siemens Magnetom Avanto, Erlangen, Germany) by using a dedicated breast coil with the patient in the prone position. Standard protocol for breast imaging including: axial scout images, precontrast axial T1-weighted (TR/TE, 450/9.6; matrix, 257x384; NEX,2; slice thickness, $4 \mathrm{~mm}$ ) and T2-weighted (TR/TE, 5600/59; matrix, 314x320; NEX,2; slice thickness, $4 \mathrm{~mm}$ ) were performed. Before and after intravenous contrast material injection 6 sequential fat-suppressed 3D T1-weighted images were obtained and subtraction was performed. A bolus of gadoversetamide (Optimark) was injected intravenously at dose of $0.2 \mathrm{mmolkg}$ of body weight. The scanning parameters for dynamic contrast-enhanced MRI were TR/TE, 4.43/1.73; matrix, 336x448; NEX, 1; slice thickness, $1.2 \mathrm{~mm}$; flip angle, $10^{\circ}$; FOV, $3.4 \times 3.4 \mathrm{~cm}$, respectively. TIC patterns were categorized into three types on the images obtained during phases of contrast-enhanced dynamic imaging: the persistent pattern (type 1 ), in which the signal intensity continues to increase over time; the plateau pattern (type 2), in which the signal intensity does not change over time after its initial increase during the delayed phase; and the washout pattern (type 3), in which the signal intensity decreases after reaching the highest point of its initial increase during the delayed phase. Before the dynamic analysis, echo-planar images were obtained with diffusion gradients in the $\mathrm{x}, \mathrm{y}, \mathrm{z}$ planes at $\mathrm{b}$ values of $0,50,200,500$ and $800 \mathrm{~s} / \mathrm{mm}^{2}$. DWI sequences were obtained with the following parameters: TR/TE, 8700/109; matrix, 96x192; NEX,2; slice thickness, $4 \mathrm{~mm}$. ADC maps were created automatically. Calculations were made based on mean ADC maps of the circular sampling region of interest (ROI), with care taken to perform measurements in solid rather than necrotic/cystic areas. The ROIs were 10$100 \mathrm{~mm}^{2}$ in size. Morphological features, ADC values and calculation of time-intensity curves (TIC) of the enhancing regions at several areas were evaluated in all patients. All MRI and US 
studies were examined by the same experienced radiologist.

MRI findings were classified according to the Breast Imaging Reporting and Data System (BI-RADS 5th edition) MRI lexicon developed by the American College of Radiology.

\section{Results}

The mean age of the patients was 37.5 years (range 20-52 years). History of breastfeeding has been reported in 6 patients and use of oral contraceptive has been reported in 5 patients. In all patients, a palpable painful breast lump was the initial clinical presentation. Additional findings include erythema $(n=2)$, thickenning of the skin $(n=1)$, axillary lymphadenopathy on the same side $(n=2)$ and nipple discharge $(n=3)$. Histopathologic evaluation was performed following US and MR imaging and analysis was compatible with IGM in all cases (Fig 1).

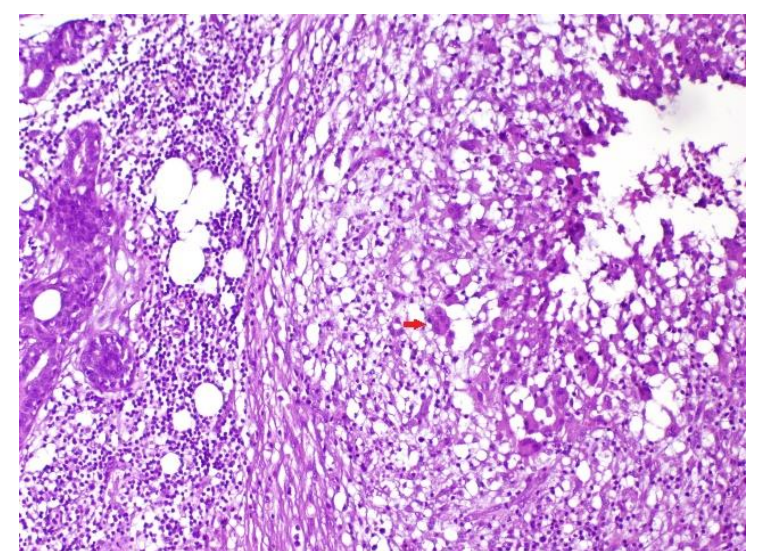

Figure 1: Lobular chronic inflammation and noncaseating granuloma with lymphocytes, plasma cells, epithelioid histiocytes, multinucleated giant cells. Right arrow indicates the multinucleated giant cells. (H\&amp;E, ×200).

US showed inflammation findings and lesions in all patients. Single or multiple irregular margined, heterogenous, hypoechoic masses which were connected to dilated tubular ductal structures with fingerlike aspects and hyperechoic debris within the ducts, were identified in 6 patients (Fig 2a). Four of patients had just indistinct bordered, different sized hypoechoic masses at the same quadrant without dilated ducts (Fig 2b). There was also increased arterial and venous flow in within all hypoechoic masses at color doppler US imaging compared to normal tissue. In three patients there were dilated ductal structures associated with surronding parenchymal and skin edema. Fistula formation, openning to skin, connected with fluid-filled dilated ducts was noted in two patients. There were increased parenchymal echo pattern around the hypoechoic masses and dilated ductal structures which were compatible with parenchymal and periductal inflammation in 7 patients. In one patient, there were multiple complex cysts with internal echoes in the affected area without any surronding parenchymal inflammation or dilated ducts. Associated axillary adenopathy was seen in 2 patients.
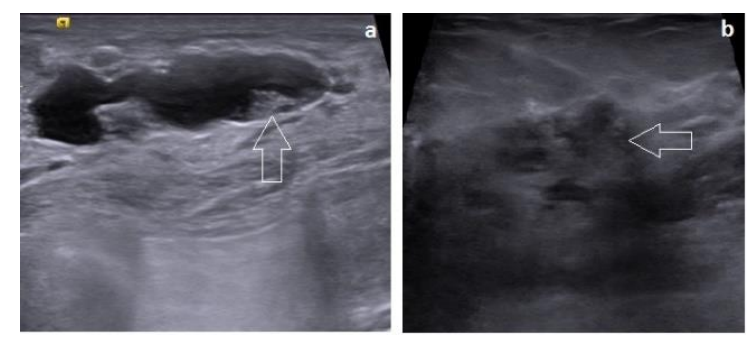

Figure 2: a US image shows hyperechoic debris within the dilated duct (open arrow). b US reveals indistinct bordered hypoechoic mass (open arrow).

The lesions of IGM showed low signal intensity on $\mathrm{T} 1$ images, high signal intensity on $\mathrm{T} 2$ images on non-contrast MR imaging series. On DCE-MRI, we observed non-mass-like enhancement in eleven patients and mass-like enhancement in one patient. The patient with mass-like enhancement, had two homogeneous contrast enhancing masses (Fig 3a). Non-masslike enhancement has involved one or two quadrants of the breast. Segmentalheterogeneous enhancement pattern $(n=7 / 12)$, segmental homogeneous enhancement pattern $(n=2 / 12)$ and diffuse heterogeneous enhancement pattern $(n=2 / 12)$ were identififed in the patients (Fig 3b). In addition, two patients had ring-like enhancement pattern. The other common finding was ductal dilatation. In nine patients, there were ductal dilatation with periductal enhancement within or around the enhancing areas. TIC of the enhancing regions were established in all patients. Kinetic curves were obtained from the centre of lesions. Nonmass-like enhancement or periductal enhancement areas usually showed type 1 or type 2 enhancement patterns or both (Table 1). Type 3 enhancement pattern was also seen in 6 patients besides the type 1 and type 2 enhancement patterns (Fig 4). Type 2 kinetic 
curves has been observed in the case with masslike enhancement (Table 1). Type 3 kinetic curve was seen in 6 patients $(50 \%)$, type 2 kinetic curve was seen in 11 patients $(91.6 \%)$. In one patient, kinetic curves changed from type 3 to type 1 after 6 months following steroid therapy (Fig 5). Histopathologic analysis was consistent with diffuse granulomatous inflammation prior to steroid therapy (Fig 6).

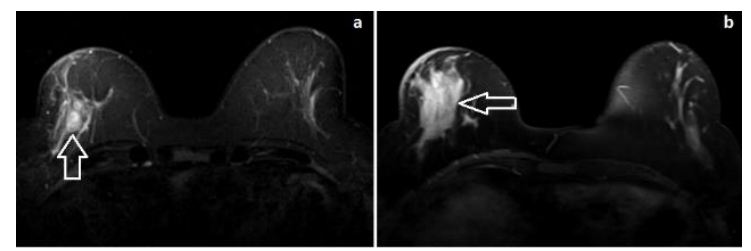

Figure 3: a DCE-MRI shows well-margined, contrast-enhancing mass (open arrow) in the right breast. b DCE-MRI reveals heterogeneous nonmass-like enhancement pattern in the right breast.

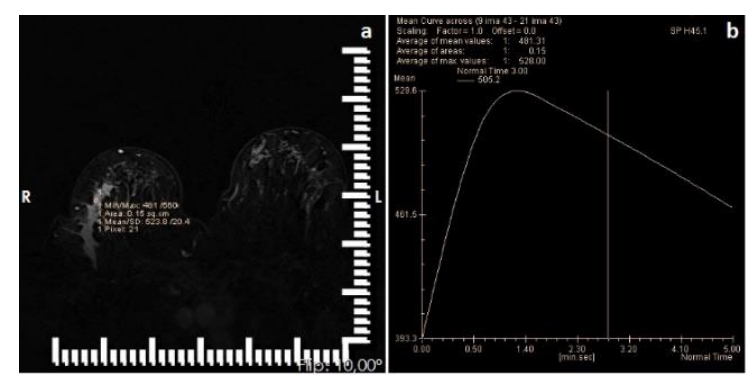

Figure 4: 49-year-old woman with breast tenderness. DCE-MRI (a), TIC of the lesion (b). DCE-MRI shows non-mass-like enhancement in the outer-lower quadrant (a). Type 3 enhancement curve is seen on TIC (b).

Diffusion images and ADC values were obtained in all patients. ADC values were calculated within the mass like, non-mass-like enhancing regions and periductal enhancement areas. ADC values were shown in the Table 1. The mean ADC value of the lesions was $1.01 \pm$ $0.06\left(\times 10^{-3} \mathrm{~mm}^{2} / \mathrm{s}\right)$ of this study.

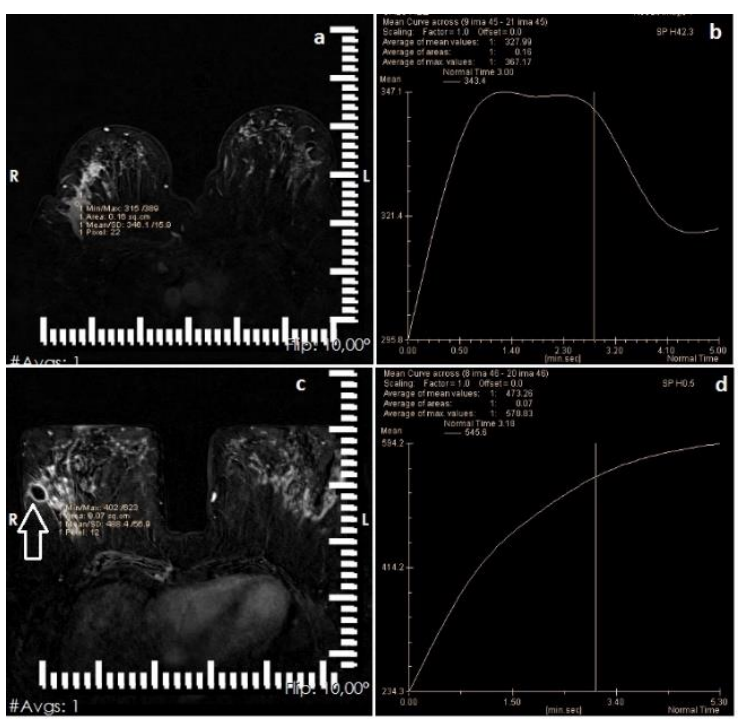

Figure 5: 32-year-old-woman with palpable breast lump. DCE-MRI (a, c), TIC of the lesion (b, d). (a) and (b) images reveal MRI findings of initial presentation, (c) and (d) images show MRI findings of patient after 6 months following steroid therapy. DCE-MRI (a) shows non-mass-like enhancement in the outer quadrant and Type 3 curve was obtained within this area on TIC (b). After 6 months, abscess formation (open arrow) has developed besides nonmass-like enhancement area (c) and kinetic curves changed from type 3 to type 1 within the lesion (d).

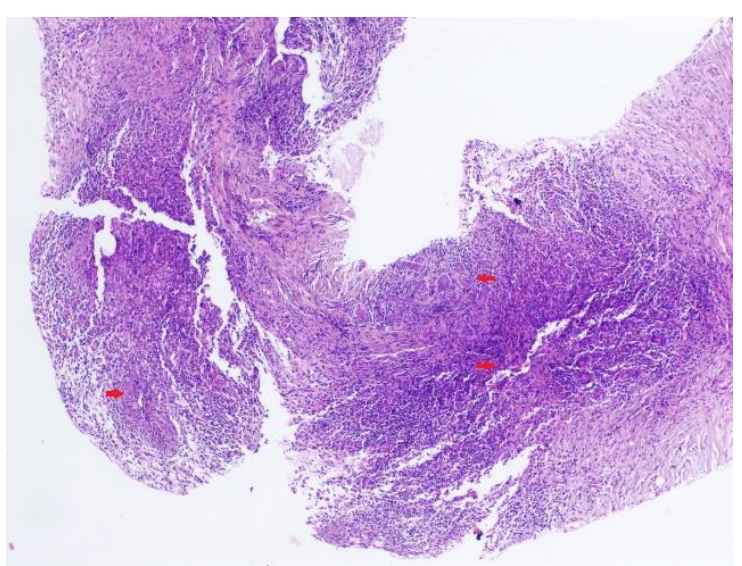

Figure 6: Diffuse granulomatous inflammation; The breast stroma is involved by a dense inflammatory process consisting of granulomas (right arrows) and a background of acute and chronic inflammatory cells. Left arrow showing residual asini of a lobule.(H\&amp;E, ×40).

The BI-RADS MRI scores of the lesions were BI-RADS 4 in all cases. 
Table 1. The contrast enhancement patterns and ADC values of cases

\begin{tabular}{|c|c|c|c|c|}
\hline Case & $\begin{array}{l}\text { Non- } \\
\text { mass- } \\
\text { like } \\
\text { enhanc } \\
\text { ement }\end{array}$ & $\begin{array}{c}\text { Mass } \\
\text {-like } \\
\text { enha } \\
\text { nce } \\
\text { ment }\end{array}$ & $\begin{array}{c}\text { Periduc } \\
\text { tal } \\
\text { enhanc } \\
\text { ement }\end{array}$ & $\begin{array}{c}\text { Mean } \\
\text { ADC* } \\
(\mathrm{x} \\
10^{-3} \mathrm{~m} \\
\left.\mathrm{~m}^{2} / \mathrm{s}\right)\end{array}$ \\
\hline 1 & - & - & Type 2 & 1.065 \\
\hline 2 & Type 1-2 & - & $\begin{array}{c}\text { Type 1- } \\
2\end{array}$ & 1.154 \\
\hline 3 & Type 1-2 & - & - & 0.974 \\
\hline 4 & 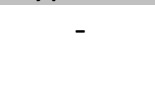 & $\begin{array}{c}\text { Type } \\
2\end{array}$ & - & 0.979 \\
\hline 5 & $\begin{array}{c}\text { Type 1- } \\
2-3\end{array}$ & - & Type 1 & 0.924 \\
\hline 6 & $\begin{array}{c}\text { Type 1- } \\
2-3\end{array}$ & - & Type 1 & 1.047 \\
\hline 7 & Type 1-2 & - & $\begin{array}{c}\text { Type 1- } \\
2\end{array}$ & 0.949 \\
\hline 8 & Type 1-3 & - & Type 1 & 1.029 \\
\hline 9 & Type 1-2 & - & $\begin{array}{c}\text { Type 1- } \\
2\end{array}$ & 0.985 \\
\hline 10 & Type 2-3 & - & Type 1 & 0.997 \\
\hline 11 & $\begin{array}{c}\text { Type } 1- \\
2-3\end{array}$ & - & Type 1 & 1.052 \\
\hline 12 & $\begin{array}{c}\text { Type 1- } \\
2-3\end{array}$ & - & - & 0.982 \\
\hline
\end{tabular}

\section{Discussion}

IGM is a chronic inflammatory benign disease of breast which was initially reported by Kessler and Wolloch (3). It predominantly affects women of childbearing age. Women with IGM typically present with palpable breast mass, pain, tenderness, and skin ulceration. The pathogenesis is not clear. The postulated causes have included autoimmune disease, use of oral contraceptives, undetected organism and breastfeeding $(4,5)$. No autoimmune disease has been seen in our cases, however use of oral contraceptives and history of breastfeeding have been reported in some of our patients.

Imaging modalities include mammography, US and MRI for the diagnosis of IGM. Mammography findings are considered nonspecific. US features of IGM are inhomogenous, indistinct margined, irregular hypoechoic masses associated with tubular structures, posterior shadowing, parenchymal heterogenity or hypoechogenity in the surrounding tissue and abcess formation with or without sinus tracts to the skin $(1,2,6-8)$. The Doppler US usually reveals increased vascularity in the affected area $(2,7,9,10)$. In our study, the most common finding was hypoechoic, heterogenous mass with ductal dilatations. Increased vascularity within the lesions was seen in all patients compared to normal tissue. In contrast to relevant reports, there were increased parenchymal echo pattern in the surrounding tissue due to inflammation in our report $(11,12)$. Han et al. reported that increased echo pattern in the surrounding tissue corresponded to a fibrous wall of confluent granulomas. Fistula formation, openning to skin was found in two patients. Although US findings of IGM are varied and nonspecific, multiple hypoechoic masses with tubular extensions, collections, inflammation in the surrounding tissue and clinical findings can be helpful for the diagnosis of IGM. Neverthless, US and mammography findings can not usually differentiate malignity from IGM.

MRI, DCE-MRI and diffusion MRI findings have been commonly used for the diagnosis and characterization due to morphologic attributes, contrast enhancement patterns and ADC values of the suspected lesions identified by mammography or US. MRI features are also helpful for detection of the extension of the masses and the lesions which has not been identified by mammograpy or US. Hitherto MRI features of IGM have been identified in a few reports $(2,6,7,9-11,13-16)$. Imaging features of IGM are highly variable. In the literature, non-contrast MRI of IGM showed tubular dilatations with segmental heterogeneity which was hypointense on $\mathrm{T} 1$ images and hyperintense on T2 images concordant to our report $(6,9,11,13)$.

DCE-MRI is useful for identification of enhancement patterns and kinetic curves by using TIC, as well as morphological characteristics and extension of the lesion. Conrast enhancement patterns are differed due to histopathologic stage of IGM (11). Both mass-like and non-mass-like enhancement patterns may be seen in IGM, however nonmass-like heterogeneous enhancement pattern is the most frequent enhancement pattern in $\operatorname{IGM}(2,6,13)$. The other enhancement patterns of IGM are segmental, diffuse, ductal, clumped, reticular, ring-like and grape-like enhancement patterns. In our report, non-mass-like enhancement pattern was the most common 
pattern. The order of frequency of non-masslike enhancement patterns was segmentalheterogeneous, segmental homogeneous and diffuse heterogeneous enhancement patterns $(\mathrm{n}=5, \mathrm{n}=2, \mathrm{n}=2$, respectively). Grape-like enhancement pattern has been seen in 2 patients, which suggests the abscess formation or collection. No clumped, reticular and ring-like enhancement patterns were noted in this study.

Morphologic features can be indistinguishable for malignancy and IGM. Unlike mass lesions, non-mass-like enhancement lesions exhibit poorly defined boundaries, leading to difficulty in the analysis of morphology. Malignant lesions such as ductal carcinoma in situ (DCIS), invasive lobular cancer and benign fibrocystic changes are likely to present as non-mass-like enhancement like IGM. TICs are very useful for differentiating malignancy from benign lesions. Type 1 curve is regarded as benign, Type 2 is suspicious for malignancy and Type 3 is highly suggestive for malignant lesions $(17,18)$. Several studies reported that the sensitivity for the detection of breast carcinomas, have ranged from $83 \%$ to $96 \%$ (19). Breast malignancy can manifest with various morphological features and enhancement patterns. Spiculated margin, rim enhancement for masses, and segmental or clumped ductal enhancement for non-mass lesions and type 3 curves are a hallmark of malignancy on MR images (17). The most commonly reported MR imaging manifestation of ductal carcinoma in situ is clumped nonmass-like enhancement in a ductal, linear, segmental, or regional distribution (20). There is wide variability in the reported enhancement kinetic curve of DCIS, with the most common pattern being early enhancement with plateau kinetics (type 2); the plateau enhancement kinetic curve is more commonly seen than type 3 or type 1 enhancement kinetics (20). Although IGM generally show benign kinetic curves; in our report, similar to malignancy or DCIS, type 2 and type 3 kinetic curves have been seen in some of the lesions. In the literature, some reports also showed type 2 and type 3 kinetic curves in IGM $(2,6,7,10,11)$. Nevethless, change of kinetic curves from type 3 curves to type 1 curves after drug therapy, may help to differentiate IGM from malignancy.

DWI help to differentiate benign lesions from malignancy due to cellularity of the lesion by calculating ADC values on masses and non-mass-like lesions. Previous studies have shown an inverse correlation between cellular density and ADC values, with malignancies having higher cellularity and lower ADC values than benign lesions (21). The mean ADC values of malignant and benign tumors from previous studies, were 0.99 and $1.49 \times 10^{-3} \mathrm{~mm}^{2} / \mathrm{sec}$, respectively and threshold value of ADC was at around 1.23 $\times 10^{-3} \mathrm{~mm}^{2} / \mathrm{sec}$ in breast MRI (22). Although IGM is a benign disease, our results showed that ADC values of IGM were similar to malignancies previously reported. $(22,23)$. Epitheloid cells, lymphocytes, noncaseating, nonvasculitic granulomatous inflammatory reaction and microabscess formation may lead to lower ADC values due to higher cellular density in IGM. Thus, DWI findings can not always differentiate malignancy from IGM. Evaluating DWI findings with US and DCEMRI findings may increase accuracy of diagnosis.

The other causes of chronic inflammatory diseases, such as Wegener granulomatous, fat necrosis, tuberculosis, fungal infection and abscess should be excluded pathologically in the diagnosis of IGM (5). Fat necrosis is benign nonsuppurative inflammatory disease of breast adipose tissue which occurs most commonly after trauma. The most common mammography findings of fat necrosis are oil cysts, coarse calcifications, microcalcifications or focal asymmetries and spiculated masses. US usually shows cystic masses with mural nodules or internal echogenities or hypoechoic solid masses. MRI findings of fat necrosis ranges from lipid cysts to round, oval masses is the result of the amount of fat, inflammatory process and fibrosis. Fat necrosis is generally isointense to fat tissue on $\mathrm{T} 1$ and T2 images, however signal intensitites can change due to hemorrhagic or inflammatory content of fat necrosis. On DCE-MRI, fat necrosis shows homogeneous or heterogeneus enhancement. The imaging findings of fat necrosis can mimic breast malignity or IGM and biopsy should be needed for the diagnosis $(6$, $24)$. Isolated abscess formation can also mimic IGM. Presence of dilated ducts, fistula formation or microabscess can help differentiate IGM from isolated abscess formation (6).

The limited number of patients and retrospective design of the study are the main 
limitations of this study. Statistical analysis could not performed due to number of patients. Histopathologic stage of the lesions were not described, hence correlation between histopathologic stage of disease and kinetic curves, ADC values could not been evaluated in this study.

\section{Conclusion}

We conclude that US findings and morphological features of IGM on MRI are variable and nonspecific. DCE-MRI and DWI features may help for diagnosis of IGM. IGM can sometimes show type 3 kinetic curves like malignancies, however changing type 3 curves to type 1 curves after treatment, may be suggestive for diagnosis of IGM. ADC values of IGM are generally similar to malignity. Although, the combination of morphological characteristics, diffusion and DCE-MRI features of the lesion may be helpful for the diagnosis of IGM, biopsy still remains the main method of definite diagnosis for IGM.

\section{References}

1. Hovanessian Larsen LJ, Peyvandi B, Klipfel N, et al. Granulomatous lobular mastitis: imaging, diagnosis, and treatment. AJR Am J Roentgenol. 2009 Aug;193(2):574-81.

2. Ozturk M, Mavili E, Kahriman G, et al. Granulomatous mastitis: radiological findings. Acta Radiol. 2007 Mar;48(2):150-5.

3. Kessler E. Wolloch Y. Granulomatous mastitis: a lesion clinically simulating carcinoma. Am J Clin Pathol 1972;58:642-646

4. Going JJ, Anderson TJ, Wilkinson S, et al. Granulomatous lobular mastitis. J Clin Pathol 40:535-540

5. Imoto $\mathrm{S}$, Kitaya $\mathrm{T}$, Kodama $\mathrm{T}$, et al. Idiopathic granulomatous mastitis: case report and review of the literature. Jpn J Clin Oncol 1997; 27: 274-277

6. Dursun M, Yilmaz S, Yahyayev A, et al. Multimodality imaging features of idiopathic granulomatous mastitis: outcome of 12 years of experience. Radiol Med. 2012 Jun;117(4):529-38.

7. Tuncbilek N, Karakas HM, Okten OO. Imaging of granulomatous mastitis: assessment of three cases. Breast. 2004 Dec;13(6):510-4.

8. Han BK, Choe YH, Park JM, et al. Granulomatous mastitis: mammographic and sonographic appearances. AJR Am J Roentgenol. 1999 Aug;173(2):317-20

9. Yıldız S, Aralasmak A, Kadıoglu H, et al. Radiologic findings of idiopathic granulomatous mastitis. Med Ultrason. 2015 Mar;17(1):39-44.
10. Al-Khawari HA, Al-Manfouhi HA, Madda JP, et al. Radiologic features of granulomatous mastitis. Breast J. 2011 Nov-Dec;17(6):645-50.

11. Kocaoglu M, Somuncu I, Ors F, et al. Imaging findings in idiopathic granulomatous mastitis. A review with emphasis on magnetic resonance imaging. J Comput Assist Tomogr. 2004 SepOct;28(5):635-41.

12. Memis A, Bilgen I, Ustun EE, et al. Granulomatous Mastitis: Imaging findings with histopathologic correlation. Clin Radiol. 2002 Nov;57(11):1001-6.

13. Aslan H, Pourbagher A, Colakoglu T. Idiopathic granulomatous mastitis: magnetic resonance imaging findings with diffusion MRI. Acta Radiol. 2016 Jul; 57(7):796-801

14. Van Ongeval C, Schraepen T, Van Steen A, et al. Idiopathic granulomatous mastitis. Eur Radiol. 1997;7(7):1010-2.

15. Schelfout K, Tjalma WA, Cooremans ID, et al. Observations of an idiopathic granulomatous mastitis. Eur J Obstet Gynecol Reprod Biol. 2001 Aug; 97 (2): 260-262

16. Tokunaga E, Kimura Y, Kitamura K, et al. Granulomatous lobular mastitis misdiagnosed as breast carcinoma. Breast J. 2004 May-Jun;10(3):2612

17. Tse GM, Chaiwun B, Wong KT, et al. Magnetic resonance imaging of breast lesions-a pathologic correlation. Breast Cancer Res Treat. 2007 May;103(1):1-10. Epub 2006 Oct 11.

18. Yang S-N, Li F-J, Chen J-M, et al. Kinetic curve type assessment for classification of breast lesions using dynamic contrast-enhanced MR imaging. PLoS One 2016 7;11(4):e0152827. Epub 2016 Apr 7.

19. Kvistad KA, Rydland J, Vainio J, et al. Breast Lesions: Evaluation with Dynamic Contrastenhanced T1-weighted MR imaging and with T2*weighted First-Pass Perfusion MR Imaging. Radiology. 2000 Aug;216(2):545-53.

20. Heather I. Greenwood, Samantha L. Heller, Sungheon Kim, et al. Ductal Carcinoma in Situ of the Breasts: Review of MR Imaging Features. Radiographics. 2013 Oct;33(6):1569-88.

21. Woodhams R, Ramadan S, Stanwell P, et al. Diffusion-weighted Imaging of the Breast: Principles and Clinical Applications. Radiographics. 2011 JulAug;31(4):1059-84.

22. Tsushima Y, Takahashi-Taketomi A, Endo K. Magnetic resonance (MR) differential diagnosis of breast tumors using apparent diffusion coefficient (ADC) on 1.5-T. J Magn Reson Imaging. 2009 Aug;30(2):249-55.

23. Lacconi C. Diffusion and perfusion of the breast. Eur J Radiol. 2010 Dec;76(3):386-90.

24. Kerridge WD, Kryvenko ON, Thompson A, et al. Fat Necrosis of the Breast: A Pictorial Review of the Mammographic, Ultrasound, CT, and MRI Findings with Histopathologic Correlation. Radiol Res Pract. 2015;2015:613139. 